\title{
Temperature and reproductive metabolism in macrobenthic populations*
}

\author{
Thomas Brey** \\ Alfred Wegener Institute for Polar and Marine Research, PO Box 120161, D-27515 Bremerhaven, Germany
}

\begin{abstract}
Clarke (1987; Mar Ecol Prog Ser 38:89-99) analysed the effects of variation in maintenance metabolic costs with temperature on reproductive metabolism in poikilothermic animals. Based on model calculations, he concluded that annual mass-specific gonad production (GP) and the share of assimilated energy used for reproductive purposes (RE) are affected in opposite ways by temperature. In animals of similar size and ecology either GP will decrease with decreasing temperature if RE remains constant or RE will increase with decreasing temperature if GP remains constant. Empirical data on productivity of marine benthic invertebrate populations suggest that the evolutionary adaptation of gonad metabolism tends toward changing GP and maintaining RE independent of temperature.
\end{abstract}

KEY WORDS: Macrozoobenthos - Reproduction - Temperature

\section{INTRODUCTION}

Temperature affects metabolism in poikilotherms, and many empirical investigations comparing species from different regions show basic metabolic rates to be positively related to ambient temperature (Musayeva \& Shushinka 1978, Ivleva 1980, Robinson et al. 1983, and others). Empirical investigations dealing with the effects of this relationship on animal productivity have focused almost exclusively on somatic production (Banse \& Mosher 1980, Plante \& Downing 1989, Morin \& Bourassa 1992 and others), largely ignoring that fraction of incoming energy used for reproductive purposes.

Clarke (1987) was the first to explore how the relation between temperature and basic metabolism may affect reproduction. He analysed 2 measures of reproductive metabolism: gonad productivity (GP), i.e. annual mass-specific gonad production, and reproductive effort (RE), i.e. the share of assimilated energy used for reproductive purposes. From model computations based on a few published individual energy budgets, Clarke (1987) concluded that GP and RE are

\footnotetext{
-Alfred Wegener Institute Publication No. 803

•-E-mail: tbrey@awi-bremerhaven.de

affected in different ways by temperature. In animals of similar size and ecology either GP will decrease with decreasing temperature if $R E$ remains constant, or RE will increase with decreasing temperature if GP remains constant.

In this study I analysed the available data on population dynamics of marine benthic invertebrate populations to establish whether or not there are general trends in GP and RE related to temperature. The results are discussed in light of possible evolutionary strategies of adaptation to different temperature environments.

\section{The model}

Clarke (1987) established the following model to describe the partitioning of assimilated energy into various sinks in a mature female animal:

$$
A=P_{\mathrm{s}}+R_{\mathrm{s}}+R_{\mathrm{a}-\mathrm{s}}+P_{\mathrm{g}}+R_{\mathrm{g}}+R_{\mathrm{a}-\mathrm{g}}+R_{\mathrm{b}}
$$

where $A$ is assimilation, $P_{\mathrm{s}}$ and $P_{\mathrm{g}}$ somatic and gonad production, $R_{\mathrm{s}}$ and $R_{\mathrm{g}}$ respiratory costs of somatic and gonad production, $R_{\mathrm{a}-\mathrm{s}}$ and $R_{\mathrm{a}-\mathrm{g}}$ respiratory costs of behavioural activity associated with somatic production and reproduction, and $R_{\mathrm{b}}$ is basic maintenance metabolism. He defined 2 measures of reproductive 
metabolism: (1) GP (called reproductive output, RO, by Clarke)

$$
\mathrm{GP}=P_{\mathrm{g}} / M
$$

(where $M$ is mean body mass during the period of observation), i.e. GP is the mass-specific gonad production, and (2) annual reproductive effort RE,

$$
\mathrm{RE}=\left(P_{\mathrm{g}}+R_{\mathrm{g}}+R_{\mathrm{a}-\mathrm{g}}\right) / A
$$

i.e. the proportion of assimilated energy used for reproductive purposes.

Clarke (1987) concluded from his model calculations that, under certain assumptions, the differences in $R_{\mathrm{b}}$ for any 2 temperatures $T_{1}<T_{2}$ within the physiological range will result in either

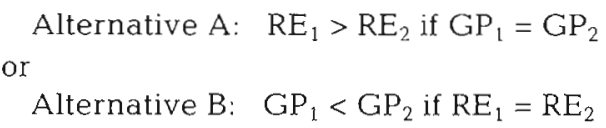

\section{Empirical relations}

Clarke (1987) confined his model calculations to the annual energy budget of a single sexually mature female. This model can be applied to populations, provided there are no intrinsic differences in the physiology of cold and warm water populations, such as an elevated basic metabolism at low temperatures (see Clarke 1991). Brey \& Clarke (1993) and Arntz et al. (1994) gave evidence that differences in growth and productivity of benthic populations from different regions are mainly related to temperature and food availability, hence I assume the above model to be valid at the population level, too.

\section{METHODS}

Only a very few publications on population dynamics of benthic invertebrates cover all parts of the energy budget. Respiration has been measured very infrequently, and no data including all components of total respiration could be found. Therefore only half of Clarke's (1987) evolutionary couplet, i.e. the relation between GP and temperature, can be analysed. On the population level, Clarke's measure of reproductive output, $G P=P_{g} / B$ ( $B$ is population biomass) is a measure equivalent to the $P_{\mathrm{s}} / B$ ratio generally used to describe somatic productivity in benthic invertebrate populations. The hypotheses to be tested are:

\footnotetext{
$\mathrm{H}_{0}$ : there is no positive relation between GP $\left(=P_{\mathrm{g}} / B\right)$ and temperature; and
}

$\mathrm{H}_{\mathrm{A}}$. there is a positive relation between GP and temperature.
Confirmation of $\mathrm{H}_{0}$ would indicate that 'Alternative B' is to be rejected, whereas confirmation of $H_{A}$ would point towards rejection of 'Alternative A'.

GP was computed from published data on 88 marine benthic invertebrate populations inhabiting subtropical, boreal and polar environments (Table 1). All mass data were converted to $\mathrm{kJ}$ where necessary

Temperature, mean individual body mass and main taxa (Mollusca, Crustacea, Echinodermata) were checked for significant effects on GP by analysis of covariance (ANCOVA). Subsequently, the relation between GP and temperature was analysed by Spearman rank correlation.

\section{RESULTS}

Table 2 shows the results of the ANCOVA analysing the effects of $T, \log (M)$ and taxon (Mollusca, Crustacea, Echinodermata) on $\log (G P)$. There is no significant relation between $M$ and GP nor any interaction between $M$ and taxon (Table 2A). GP is significantly affected by temperature and the temperature effect differs significantly among taxa (Table 2B). Spearman rank correlations indicate a significant positive relation between temperature and GP for all data $(\rho=0.435, p<0.001)$ as well as in Mollusca $(\rho=0.388, p=0.005)$ and Crustacea $(\rho=$ $0.595, p=0.032$ ) separately (Fig. 1). There is no significant correlation in Echinodermata $(\rho=0.332, p=$ 0.148 ); however, if the 2 data points referring to Sterechinus neumayeri are excluded, the correlation becomes highly significant $(\rho=0.638, p=0.009)$. These results indicate $H_{A}$, that there is a positive relation between GP and temperature, has to be generally accepted.

\section{DISCUSSION}

Many empirical investigations have demonstrated a strong negative relationship between individual body mass and mass-specific basic metabolic rates (see Ivleva 1980, Robinson et al. 1983, Calder 1985, and others) as well as derived parameters such as population $P_{\mathrm{s}} / B$ ratio (Banse \& Mosher 1980, Schwinghamer et al. 1986, Plante \& Downing 1989, Brey 1991, Morin \& Bourassa 1992). Surprisingly there is no such relation between body mass and GP $\left(=P_{\mathrm{g}} / B\right.$ ratio $)$ detectable in the present data (Table 2). Thus, GP in benthic invertebrates seems to be independent of body mass, whereas annual gonad production is positively related to body mass, indicating that an increase in gonad output may be one of the evolutionary advantages of larger body size. 
Table 1. The 88 data sets this investigation is based on (see 'Data Sources' for full citations). M: mean individual body mass (kJ); $T$ : mean water temperature (K); GP: annual gonad productivity, $P_{\mathrm{g}} / B\left(\mathrm{yr}^{-1}\right.$ ) (see 'Methods')

\begin{tabular}{|c|c|c|c|c|c|}
\hline Source & Species & Taxon & $M$ & $T$ & GP \\
\hline Otto (1976) & Ancylus fluviatilis & Mollusca & 0.0074 & 280.0 & 0.569 \\
\hline Griffiths (1977), Griffiths \& King (1979) & Aulacomya ater & Mollusca & 11.9886 & 288.5 & 0.865 \\
\hline McLachlan et al. (1979) & Bullia rhodostoma & Mollusca & 0.4963 & 292.0 & 0.500 \\
\hline Moore \& Lopez (1969) & Chione cancellata & Mollusca & 1.1103 & 299.0 & 0.414 \\
\hline $\operatorname{Vahl}(1981 \mathrm{a}, \mathrm{b})$ & Chlamys islandica & Mollusca & 26.6370 & 280.0 & 0.123 \\
\hline \multirow[t]{2}{*}{ Shafee \& Conan (1984) } & Chlamys varia & Mollusca & 22.8026 & 285.0 & 0.067 \\
\hline & & & 17.4043 & 285.0 & 0.151 \\
\hline \multirow{4}{*}{ Griffiths $(1981 a, b)$} & Choromytilus meridionalis & Mollusca & 4.1797 & 292.0 & 5.288 \\
\hline & & & 4.6529 & 292.0 & 2.908 \\
\hline & & & 4.0241 & 292.0 & 4.338 \\
\hline & & & 4.9919 & 292.0 & 5.063 \\
\hline Aldridge \& McMahon (1978) & Corbula manilensis & Mollusca & 5.0187 & 293.9 & 0.485 \\
\hline Dame $(1972 a, b, 1976)$ & Crassostrea virginica & Mollusca & 4.7709 & 292.0 & 0.327 \\
\hline Ansell et al. (1972) & Donax incarnatus & Mollusca & 0.1919 & 301.0 & 0.408 \\
\hline \multirow[t]{2}{*}{ Barkai \& Griffiths (1988) } & Haliotis midae & Mollusca & 1093.3330 & 287.0 & 0.326 \\
\hline & & & 950.0000 & 292.0 & 0.558 \\
\hline Richardson (1979) & Lissarca miliaris & Mollusca & 0.0066 & 272.2 & 0.114 \\
\hline \multirow[t]{2}{*}{ Brey et al. (1993) } & Lissarca notorcadensis & Mollusca & 0.0198 & 272.0 & 0.128 \\
\hline & & & 0.0202 & 272.0 & 0.115 \\
\hline Gaten (1986) & Lymnaea peregra & Mollusca & 0.3845 & 283.0 & 4.820 \\
\hline Hummel (1985) & Macoma balthica & Mollusca & 0.8017 & 282.3 & 0.162 \\
\hline Hibbert $(1976,1977 a, b)$ & Mercenaria mercenaria & Mollusca & 7.2510 & 285.0 & 0.332 \\
\hline Bréthes et al. (1986) & Mesodesma arctatum & Mollusca & 2.4790 & 278.5 & 0.240 \\
\hline Kuenzler (1961) & Modiolus demissus & Mollusca & 27.6442 & 294.0 & 0.054 \\
\hline Thompson $(1984 \mathrm{a}, \mathrm{b})$ & Mytilus edulis & Mollusca & 23.7180 & 279.1 & 0.595 \\
\hline Picken (1980) & Nacella concinna & Mollusca & 2.1085 & 272.2 & 0.080 \\
\hline Nolan (1987) & Nacella concinna & Mollusca & 3.6630 & 272.2 & 0.093 \\
\hline Hughes (1972) & Nucella lapillus & Mollusca & 3.6160 & 280.0 & 1.802 \\
\hline \multirow[t]{4}{*}{ Rachor (1976) } & Nucula nitidosa & Mollusca & 0.0654 & 282.0 & 1.424 \\
\hline & & & 0.0594 & 282.0 & 1.341 \\
\hline & & & 0.0577 & 282.0 & 0.603 \\
\hline & & & 0.0918 & 282.0 & 1.044 \\
\hline Davis \& Wilson (1985) & Nucula turgida & Mollusca & 0.0933 & 283.5 & 0.481 \\
\hline \multirow[t]{2}{*}{ Wright \& Hartnoll (1981) } & Patella vulgata & Mollusca & 11.0881 & 282.0 & 0.272 \\
\hline & & & 8.9263 & 282.0 & 0.280 \\
\hline \multirow[t]{2}{*}{ MacDonald \& Bourne (1987) } & Patinopecten caurinus & Mollusca & 107.9790 & 281.5 & 0.054 \\
\hline & & & 602.1310 & 283.0 & 0.097 \\
\hline \multirow[t]{2}{*}{ Berry (1978) } & Perna perna & Mollusca & 0.7842 & 294.0 & 1.297 \\
\hline & & & 1.3066 & 294.0 & 1.010 \\
\hline Shafee (1992) & Perna picta & Mollusca & 2.5182 & 291.0 & 0.576 \\
\hline Cheung (1993) & Perna viridis & Mollusca & 4.7516 & 296.8 & 0.596 \\
\hline Seager $(1978)$ & Philine gibba & Mollusca & 1.7561 & 274.5 & 0.679 \\
\hline \multirow{2}{*}{$\begin{array}{l}\text { Holopainen (1979), Holo- } \\
\text { painen \& Hanski (1979) }\end{array}$} & Pisidium casertanum & Mollusca & 0.0018 & 280.0 & 0.180 \\
\hline & & & 0.0013 & 277.5 & 0.250 \\
\hline \multirow[t]{2}{*}{ MacDonald \& Thompson (1986) } & Placopecten magellanicus & Mollusca & 507.6315 & 278.0 & 0.236 \\
\hline & & & 221.5000 & 280.0 & 0.144 \\
\hline Hughes $(1970 a, b)$ & Scrobicularia plana & Mollusca & 2.7752 & 285.0 & 0.455 \\
\hline Paine (1971) & Tegula funebralis & Mollusca & 1.4734 & 282.1 & 0.032 \\
\hline \multirow[t]{2}{*}{ Salzwedel (1979) } & Tellina fabula & Mollusca & 0.0118 & 283.0 & 0.179 \\
\hline & & & 0.0293 & 283.0 & 0.343 \\
\hline \multirow[t]{3}{*}{ Trevallion (1971) } & Tellina tenuis & Mollusca & 0.5750 & 281.5 & 0.395 \\
\hline & & & 0.4830 & 281.5 & 0.245 \\
\hline & & & 0.3220 & 281.5 & 0.046 \\
\hline Clasing et al. (1994) & Venus antiqua & Mollusca & 7.1276 & 284.0 & 0.028 \\
\hline \multirow[t]{2}{*}{ Hastings (1981) } & Ampelisca brevicornis & Crustacea & 0.0172 & 285.0 & 0.253 \\
\hline & & & 0.0250 & 285.0 & 0.208 \\
\hline Gorny et al. (1993) & Chorismus antarcticus & Crustacea & 3.1280 & 272.0 & 0.021 \\
\hline Johnson $(1976 a, b)$ & Cirolana harfordi & Crustacea & 0.1857 & 288.0 & 0.304 \\
\hline Shafir \& Field $(1980 a, b)$ & Cirolana imposita & Crustacea & 0.0388 & 287.0 & 0.857 \\
\hline
\end{tabular}


Table 1 (continued)

\begin{tabular}{|c|c|c|c|c|c|}
\hline Source & Species & Taxon & M & $T$ & GP \\
\hline \multirow[t]{2}{*}{ Mathias (1971) } & \multirow[t]{2}{*}{ Crangonyx richmondensis } & \multirow[t]{2}{*}{ Crustacea } & 0.0128 & 282.0 & 0.042 \\
\hline & & & 0.0114 & 281.0 & 0.056 \\
\hline LaFrance \& Ruber (1985) & Gammarus mucronatus & Crustacea & 0.0048 & 281.0 & 0.440 \\
\hline Marchant \& Hynes (1981) & Gammarus pseudolimnaeus & Crustacea & 0.0246 & 281.0 & 0.065 \\
\hline \multirow[t]{2}{*}{ Mathias (1971) } & \multirow[t]{2}{*}{ Hyalella azteca } & \multirow[t]{2}{*}{ Crustacea } & 0.0038 & 282.0 & 0.368 \\
\hline & & & 0.0035 & 283.0 & 0.252 \\
\hline Willows (1987) & Ligia oceanica & Crustacea & 0.4461 & 282.5 & 0.164 \\
\hline Kemp et al. (1985) & Rhepoxynius abronius & Crustacea & 0.0062 & 283.5 & 0.361 \\
\hline Luxmoore $(1981,1982,1985)$ & Serolis polita & Crustacea & 0.3835 & 272.3 & 0.051 \\
\hline Dayton et al. (1974) & Acodontaster conspicuus & Echinodermata & 1355.6380 & 271.2 & 0.195 \\
\hline Singletary $(1971)$ & Amphioplus coinortodes & Echinodermata & 0.4489 & 298.0 & 0.203 \\
\hline O'Connor et al. (1986) & Amphiura filiformis & Echinodermata & 0.6822 & 284.0 & 0.467 \\
\hline \multirow[t]{2}{*}{ Lane (1977) } & \multirow[t]{2}{*}{ Mellita quinquiesperforata } & \multirow[t]{2}{*}{ Echinodermata } & 4.5992 & 298.6 & 0.424 \\
\hline & & & 8.3727 & 298.6 & 0.367 \\
\hline Singletary (1971) & Micropholis gracillima & Echinodermata & 0.4941 & 298.0 & 0.484 \\
\hline Moore \& Lopez (1966) & Moira atropes & Echinodermata & 6.1745 & 299.0 & 0.375 \\
\hline Dayton et al. (1974) & Odontaster validus & Echinodermata & 23.7790 & 271.2 & 0.157 \\
\hline McClintock et al. (1988) & Odontaster validus & Echinodermata & 28.8570 & 271.2 & 0.107 \\
\hline Singletary (1971) & Ophionepthys limicola & Echinodermata & 1.5114 & 298.0 & 0.268 \\
\hline \multirow[t]{3}{*}{ Morison (1979) } & \multirow[t]{3}{*}{ Ophionotus hexactis } & \multirow[t]{3}{*}{ Echinodermata } & 1.0106 & 274.5 & 0.137 \\
\hline & & & 0.5623 & 274.5 & 0.200 \\
\hline & & & 1.4590 & 274.5 & 0.066 \\
\hline \multirow[t]{2}{*}{ Greenwood (1980) } & \multirow[t]{2}{*}{ Parechinus angulosus } & \multirow[t]{2}{*}{ Echinodermata } & 7.4525 & 286.0 & 0.251 \\
\hline & & & 17.2774 & 287.0 & 0.129 \\
\hline Dayton et al. (1974) & Perknaster fuscus & Echinodermata & 199.2800 & 271.2 & 0.241 \\
\hline Brey $(1991)$ & Sterechinus antarcticus & Echinodermata & 2.3019 & 272.0 & 0.098 \\
\hline \multirow[t]{2}{*}{ Brey et al. (in press) } & \multirow[t]{2}{*}{ Sterechinus neumayeri } & \multirow[t]{2}{*}{ Echinodermata } & 89.4137 & 271.2 & 0.426 \\
\hline & & & 110.6756 & 271.2 & 0.434 \\
\hline Miller \& Mann (1973) & Strongylocentrotus droebachiensis & Echinodermata & 2.6690 & 279.0 & 0.156 \\
\hline
\end{tabular}

As indicated by Fig. 1, the relation between $T$ and GP is scattered, but nevertheless significantly positive in Mollusca, Crustacea and the pooled data of all 3 taxa. Within the Echinodermata, the significance level of the correlation depends on whether the 2 data points of Sterechinus neumayeri are included or not.

Table 2. Analysis of covariance (ANCOVA) of the effects of $T, \log (M)$ and Taxon on $\log (G P) ; T$ temperature; $M$ mean individual body mass. The analysis is based on the 88 data sets shown in Table 1

\begin{tabular}{|c|c|c|c|c|c|}
\hline & $d f$ & SS & MS & $F$-value & p-value \\
\hline \multicolumn{6}{|c|}{ (A) $M, T$ and Taxon as independent factors } \\
\hline$T$ & 1 & 2.371 & 2.371 & 12.442 & 0.0007 \\
\hline $\log (M)$ & 1 & 0.027 & 0.027 & 0.139 & 0.7100 \\
\hline Taxon & 2 & 0.812 & 0.406 & 2.129 & 0.1257 \\
\hline$T$ [Taxon] & 2 & 0.835 & 0.417 & 2.190 & 0.1187 \\
\hline $\log (M)$ [Taxon] & 2 & 0.372 & 0.186 & 0.997 & 0.3809 \\
\hline Residual & 79 & 15.056 & 0.191 & & \\
\hline \multicolumn{6}{|l|}{ (B) $M$ excluded } \\
\hline$T$ & 1 & 3.120 & 3.120 & 16.4151 & 0.0001 \\
\hline Taxon & 2 & 1.349 & 0.674 & 3.491 & 0.0351 \\
\hline$T$ [Taxon] & 2 & 1.357 & 0.678 & 3.512 & 0.0344 \\
\hline Residual & 82 & 15.838 & 0.193 & & \\
\hline
\end{tabular}

It remains unclear why this species shows a distinctly higher gonad productivity than other echinoderms living under similar temperature conditions. Altogether there is substantial evidence for a positive correlation of GP with $T$ in macrobenthic populations of the 3 taxa (Fig. 1). Consequently, within Clarke's model, true RE is likely to be independent of temperature. Hence, there seems to be a tendency toward Clarke's 'Alternative $B^{\prime}, G P_{1}<G P_{2}$ and $R E_{1} \approx R E_{2}$ for $T_{1}<T_{2}$ in benthic invertebrate populations.

The 2 parameters GP and RE may be interpreted as measures of alternative strategies in the evolutionary adaptation of reproductive metabolism to different conditions. If we compare 2 environments with different temperature, then the first strategy would result in more or less constant reproductive output, but at the cost of having less energy available for other metabolic demands at lower temperature. The second strategy would result in a more or less con- 


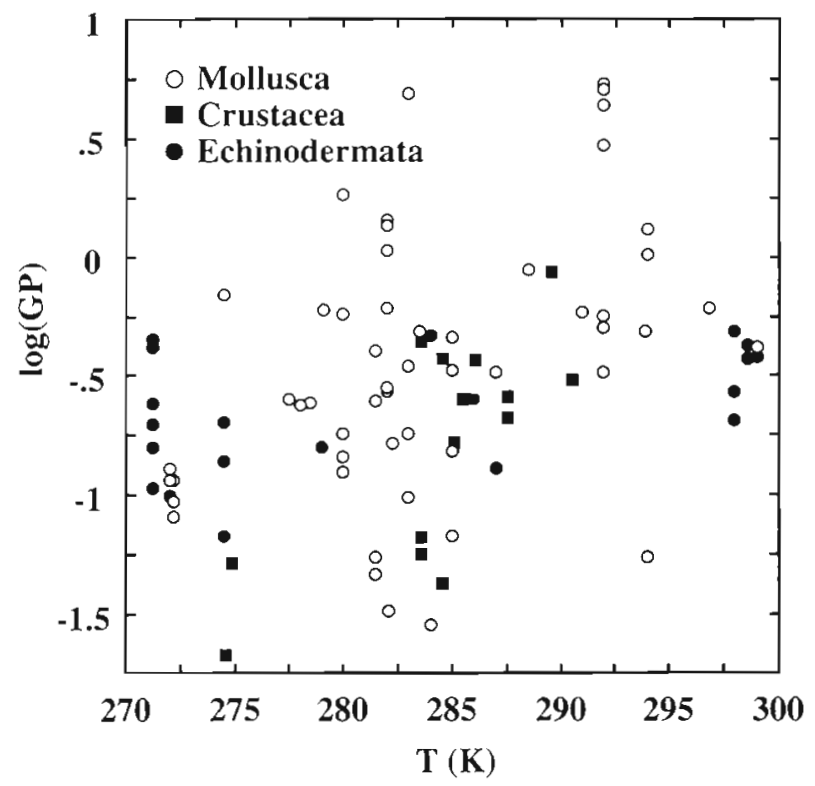

Fig. 1. Relation between gonad productivity GP $\left(=P_{\mathrm{g}} / B\right)$ (see 'Methods') and temperature (T) in Mollusca, Crustacea and Echinodermata. Spearman Rank Correlation for Mollusca: $\rho=$ 0.388, $\mathrm{p}=0.005, \mathrm{n}=54$; Crustacea: $\rho=0.595, \mathrm{p}=0.032, \mathrm{n}=14$; Echinodermata: $\rho=0.332, p=0.148, n=20 ;$ All: $\rho=0.435, p<$ $0.001, \mathrm{n}=88$

stant share of gonad metabolism in total metabolism, accepting a lower gonad productivity at lower temperature. The present results are evidence that the former strategy is not common among benthic invertebrate populations. They tend to maintain the proportion of energy invested in reproduction, irrespective of temperature while gonad productivity is reduced.

This is of particular interest for the understanding of evolutionary adaptations of reproductive strategies to low temperature environments. The widely accepted opinion is that cold water species in general are characterized by features summarized under 'Thorson's rule', such as low fecundity, large eggs, non-pelagic development and brooding, although many exceptions are known (see e.g. White 1984, Pearse \& McClintock 1991, Arntz et al. 1994). However, my analysis indicates that the evolution of these cold water reproductive strategies does not affect the relative energy investment in reproduction. Evolution seems to affect mainly the mode of reproduction, rather than the basic energetics.

Acknowledgements. Many thanks to Andy Clarke (British Antarctic Survey), who made very helpful comments on an early draft of this paper, and to Astrid Jarre-Teichmann, who helped to solve some statistical problems.

\section{LITERATURE CITED}

Arntz W, Brey T, Gallardo A (1994) Antarctic zoobenthos. Oceanogr mar Biol A Rev 32:241-304

Banse $\mathrm{K}$, Mosher S (1980) Adult body mass and annual production/biomass relationships of field populations. Ecol Monogr 50:355-379

Brey T, Clarke A (1993) Population dynamics of marine benthic invertebrates in Antarctic and subantarctic environments: are there unique adaptations? Antarct Sci 5: 253-266

Calder WA (1985) Size and metabolism in natural systems. Can Bull Fish Aquat Sci 213:65-75

Clarke A (1987) Temperature, latitude and reproductive effort. Mar Ecol Prog Ser 38:89-99

Clarke A (1991) What is cold adaptation and how should we measure it? Am Zool 31:81-92

Ivleva IV (1980) The dependence of crustacean respiration rate on body mass and habitat temperature. Int Revue ges Hydrobiol 65:1-47

Morin A, Bourassa N (1992) Modèles empiriques de la production annuelle et du rapport $\mathrm{P} / \mathrm{B}$ d'invertébrés benthiques d'eau courante. Can J Fish Aquat Sci 49:532-539

Musayeva EI, Shushkina EA (1978) Metabolic rates of planktonic animals living at different temperatures. Oceanology 18:343-346

Pearse JS, McClintock JB (1991) Reproduction of Antarctic benthic marine invertebrates: tempos, modes, and timing. Am Zool 31:65-80

Plante C, Downing JA (1989) Production of freshwater invertebrate populations in lakes. Can J Fish Aquat Sci 46: $1489-1498$

Robinson WR, Peters RH, Zimmerman J (1983) The effects of body size and temperature on metabolic rate of organisms. Can J Zool 61:281-288

Schwinghamer P, Hargrave B, Peer D, Hawkins CM (1986) Partitioning of production and respiration among size groups of organisms in an intertidal benthic community. Mar Ecol Prog Ser 31:131-142

White MG (1984) Marine benthos. In: Laws RM (ed) Antarctic ecology, Vol 2. Academic Press, London, p 421-461

\section{DATA SOURCES}

Aldridge DW, McMahon RF (1978) Growth, fecundity, and bioenergetics in a natural population of the Asiatic freshwater clam, Corbicula manilensis Philippi, from north central Texas. J mollusc Stud 44:49-70

Ansell AD, Sivadas P, Narayanan B, Trevallion A (1972) The ecology of two sandy beaches in South West India. III. Observations on the population of Donax incarnatus and D. spiculum. Mar Biol 17:318-332

Barkai R, Griffiths CL (1988) An energy budget for the South African abalone Haliotis midae Linnaeus. J mollusc Stud $54: 43-51$

Berry PF (1978) Reproduction, growth and production in the mussel, Perna perna (Linnaeus), on the east coast of South Africa. Invest Rep Oceanogr Res Inst, Durban 48: $1-28$

Bréthes JC, Desrosiers G, Fortin G (1986) Croissance et production du bivalve Mesodesma arctatum (Conrad) sur la côte nord du golfe du Saint-Laurent. Can J Zool 64: $1914-1919$

Brey T (1991) Population dynamics of Sterechinus antarcticus (Echinodermata: Echinoidea) on the Weddell Sea Shelf and slope, Antarctica. Antarct Sci 3:251-256 
Brey T, Pearse J, Basch L, McClintock J, Slattery M (in press) Growth and production of Sterechinus neumayeri (Echinoidea, Echinodermata) in McMurdo Sound, Antarctica. Mar Biol

Brey T, Starmans A, Magiera U, Hain S (1993) Lissarca notorcadensis (Bivalvia: Philobryidae) living on Notocidaris sp. (Echinoedea: Cidaridae): population dynamics in limited space. Polar Biol 13:89-95

Cheung SG (1993) Population dynamics and energy budgets of green-lipped mussel Perna viridis (Linnaeus) in a polluted harbour. J exp mar Biol Ecol 168:1-24

Clasing E, Brey T, Stead R, Navarro J, Asencio G (1994) Population dynamics of Venus antiqua (Bivalvia: Veneracea) in the Bahía de Yaldad, Isla de Chiloé, southern Chile. $\checkmark$ exp mar Biol Ecol 177:171-186

Dame RF (1972a) Comparison of various allometric relationships in intertidal and subtidal American oysters. Fish Bull US $70: 1121-1126$

Dame RF (1972b) The ecological energetics of growth, respiration and assimilation in the intertidal American oyster Crassostrea virginica. Mar Biol 17:243-250

Dame RF (1976) Energy flow in an intertidal oyster population. Estuar coast mar Sci 4:243-253

Davis JP, Wilson JG (1985) The energy budget and population structure of Nucula turgida in Dublin Bay. J Anim Ecol $54: 557-571$

Dayton PK, Robillard GA, Paine RT, Dayton LB (1974) Biological accommodation in the benthic community at McMurdo Sound, Antarctica. Ecol Monogr 44:105-128

Gaten E (1986) Life cycle of Lymnaea peregra (Gastropoda: Pulmonata) in the Leicester canal, U.K., with an estimate of annual production. Hydrobiologia 135:45-54

Gorny M, Brey T, Arntz W, Bruns T (1993) Development growth and productivity of Chorismus antarcticus (Crustacea: Decapoda: Natantia) in the eastern Weddell Sea, Antarctica. J exp mar Biol Ecol 174:261-275

Greenwood PJ (1980) Growth, respiration and tentative energy budgets for two populations of the sea urchin Parechinus angulosus (Leske). Estuar coast mar Sci 10: 347-367

Griffiths CL (1977) Reproductive cycles in littoral populations of Choromytilus meridionalis (Kr.) and Aulacomya ater (Molina) with a quantitative assessment of gamete production in the former. J exp mar Biol Ecol 30:53-71

Griffiths CL, King JA (1979) Energy expended in growth and gonad output in the ribbed mussel Aulacomya ater. Mar Biol 53:217-222

Griffiths RJ (1981a) Population dynamics and growth of the bivalve Choromytilus meridionalis (Kr.) at different tidal levels. Estuar coast Shelf Sci 12:101-118

Griffiths RJ (1981b) Production and energy flow in relation to age and shore level in the bivalve Choromytilus meridionalis (Kr.). Estuar coast Shelf Sci 13:477-493

Hastings MH (1981) The life cycle and productivity of an intertidal population of the amphipod Ampelisca brevicornis. Estuar coast Shelf Sci 12:665-677

Hibbert CJ (1976) Biomass and production of a bivalve community on an intertidal mud-flat. J exp mar Biol Ecol 25: $249-261$

Hibbert CJ (1977a) Energy relations of the bivalve Mercenaria mercenaria on an intertidal mudflat. Mar Biol 44. $77-84$

Hibbert CJ (1977b) Growth and survivorship in a tidal-flat population of the bivalve Mercenaria mercenaria from Southampton water. Mar Biol 44:71-76

Holopainen IJ (1979) Population dynamics and production of Pisidium species (Bivalvia, Spaeriidae) in the oligotrophic and mesohumic lake Pääjärvi, southern Finland. Arch Hydrobiol Suppl 54:466-508

Holopainen I. Hanski I (1979) Annual energy flow in populations of two Pisidium species (Bivalvia, Spaerijdae), with discussion on possible competition between them. Arch Hydrobiol 86:338-354

Hughes RN (1970a) An energy budget for a tidal-flat population of the bivalve Scrobicularia plana (da Costa). J Anim Ecol 39:357-381

Hughes RN (1970b) Population dynamics of the bivalve Scrobicularia plana (da Costa) on an intertidal mud-flat in north Wales. J Anim Ecol 39:333-356

Hughes RN (1972) Annual production of two Nova Scotian populations of Nucella lapillus (L.). Oecologia 8: $356-370$

Hummel H (1985) An energy budget for a Macoma balthica (Mollusca) population living on a tidal flat in the Dutch Wadden Sea. Neth J Sea Res 19:84-92

Johnson WS (1976a) Biology and population dynamics of the intertidal isopod Cirolana harfordi. Mar Biol 36:343-350

Johnson WS (1976b) Population energetics of the intertidal isopod Cirolana harfordi. Mar Biol 36:351-357

Kemp PF, Cole FA, Swartz C (1985) Life history and productivity of the phoxocephalid amphipod Rhepoxynius abronius (Barnad). J crust Biol 5:449-464

Kuenzler EJ (1961) Structure and energy flow of a mussel population in a Georgia salt marsh. Limnol Oceanogr 6: 191-204

LaFrance K, Ruber E (1985) The life cycle and productivity of the amphipod Gammarus mucronatus on a northern Massachusetts salt marsh. Limnol Oceanogr 30: $1067-1077$

Lane JM (1977) Bioenergetics of the sand dollar, Mellita quinquiesperforata (Leske 1778). PhD thesis, Univ of South Florida, Miami

Luxmoore RA (1981) The ecology of Antarctic Serolid isopods. PhD thesis, British Antarctic Survey, Natural Environment Research Council, Cambridge

Luxmoore RA (1982) Moulting and growth in serolid isopods. $J$ exp mar Biol Ecol 56:63-85

Luxmoore RA (1985) The energy budget of a population of the Antarctic isopod Serolis polita. In: Siegfried WR, Condy $\mathrm{PR}$, Laws RM (eds) Antarctic nutrient cycles and food webs. Springer, Berlin, p 389-396

MacDonald BA, Bourne NF (1987) Growth, reproductive output, and energy partitioning in weathervane scallops, Patinopecten caurinus, from British Columbia. Can J Fish Aquat Sci 44:152-160

MacDonald BA, Thompson RJ (1986) Production, dynamics and energy partitioning in two populations of the giant scallop Placopecten magellanicus (Gmelin). J exp mar Biol Ecol 101:285-299

Marchant R, Hynes HBN (1981) The distribution and production of Gammarus pseudolimnaeus (Crustacea: Amphipoda) along a reach of the Credit river, Ontario. Freshwat Biol 11:169-182

Mathias JA (1971) Energy flow and secondary production of the amphipods Hyalella azteca and Crangonyx richmondensis occidentalis in Marion Lake, British Columbia. J Fish Res Bd Can 28:711-726

McClintock JB, Pearse JS, Bosch I (1988) Population structure and energetics of the shallow-water antarctic sea star Odontaster validus in contrasting habitats. Mar Biol 99 : $235-246$

McLachlan A, Cooper C, Horst G van der (1979) Growth and production of Bullia rhodostoma on an open sandy beach in Algoa Bay. S Afr J Zool 14:49-53 
Miller RJ, Mann KH (1973) Ecological energetics of the seaweed zone in a marine bay on the Atlantic coast of Canada. III. Energy transformations by sea urchins. Mar Biol 18:99-114

Moore HB, Lopez NN (1966) The ecology and productivity of Moira atropes (L.). Bull mar Sci 16:648-667

Moore HB, Lopez NN (1969) The ecology of Chione cancellata. Bull mar Sci 19:131-148

Morison GW (1979) Studies on the growth of the sub-Antarctic ophiuroid Ophionotus hexactis. Master thesis, University of London

Nolan CP (1987) Calcification and growth rates in Antarctic molluscs. British Antarctic Survey, Cambridge, AD6/2H/ $1987 / \mathrm{N} 8$

O'Connor B, Bouwmer T, McGrath D, Raine R (1986) Energy flow through an Amphiura filiformis (Ophiuroidea: Echinodermata) population in Galway Bay, west coast of Ireland: a preliminary investigation. Ophelia 26:351-357

Otto C (1976) Production of Ancylus fluviatilis Müller (Gastropoda) in a south Swedish stream. Polskie Arch Hydrobiol 23:421-429

Paine RT (1971) Energy flow in a natural population of the herbivorous gastropod Tegula funebralis. Limnol Oceanogr 16:86-98

Picken GB (1980) The distribution, growth and reproduction of the antarctic limpet Nacella (Patinigera) concinna. J exp mar Biol Ecol 42:71-85

Rachor E (1976) Structure, dynamics and productivity of a population of Nucula nitidosa (Bivalvia, Protobranchia) in the German Bight. Ber dt wiss Komm Meeresforsch 24:296-331

Richardson GM (1979) The distribution of Antarctic marine macroalgae related to depth and substrate. Br Antarct Surv Bull 49:1-13

Salzwedel H (1979) Energy budgets for two populations of the bivalve Tellina fabula in the German Bight. Veröff Inst Meeresforsch Bremerhaven 18:257-287

Seager JR (1978) The ecology of an Antarctic ophistobranch mollusc: Philine gibba Strebel. PhD thesis, University College, Cardiff, UK

This article was submitted to the editor
Shafee MS (1992) Production estimate of a mussel population Perna picta (Born) on the Atlantic coast of Morocco. J exp mar Biol Ecol 163:183-197

Shafee MS, Conan G (1984) Energetic parameters of a population of Chlamys varia (Bivalvia: Pectinidae). Mar Ecol Prog Ser 18:253-262

Shafir A, Field JG (1980a) Importance of a small carnivorous isopod in energy transfer. Mar Ecol Prog Ser 3:203-215

Shafir A, Field JG (1980b) Population dynamics of the isopod Cirolana imposita Barnard in a kelp-bed. Crustaceana 39: 185-196

Singletary R (1971) The biology and ecology of Amphioplus coniortodes, Ophionepthys limicola, and Micropholis gracillima (Ophiuroidea: Amphiuridae). PhD thesis, University of Miami, Coral Gables

Thompson RJ (1984a) Production, reproductive effort, reproductive value and reproductive cost in a population of the blue mussel Mytilus edulis from a subarctic environment. Mar Ecol Prog Ser 16:249-257

Thompson RJ (1984b) The reproductive cycle and physiological ecology of the mussel Mytilus edulis in a subarctic, non-estuarine environment. Mar Biol 79:277-288

Trevallion A (1971) Studies on Tellina tenuis Da Costa. III. Aspects of general biology and energy flow. J exp mar Biol Ecol 7:95-122

Vahl O (1984a) Energy transformations by the Iceland scallop, Chlamys islandica (O.F. Müller) from $70^{\circ} \mathrm{N}$. I. The agespecific energy budget and net growth efficiency. $J$ exp mar Biol Ecol 53:281-296

Vahl O (1984b) Energy transformations by the Iceland scallop, Chlamys islandica (O.F. Müller) from $70^{\circ} \mathrm{N}$. II. The population energy budget. J exp mar Biol Ecol 53: 297-303

Willows RI (1987) Population and individual energetics of Ligia oceanica (L.) (Crustacea: Isopoda) in the rocky supralittoral. J exp mar Biol Ecol 105:253-274

Wright JR, Hartnoll RG (1981) An energy budget for a population of the limpet Patella vulgata. J mar biol Ass UK 61: $627-646$

Manuscript first received: June 17, 1994

Revised version accepted: March 23, 1995 